\title{
Die Garismatiese Beweging - inleidende opmerkings
}

\author{
J I DE WET
}

Wat hier volg is nie ' $n$ volledige behandeling van die garismatiese beweging nie. Dit is slegs inleidende opmerkings in verband met die vernaamste kenmerke van hierdie wêreldwye beweging. Om iets van die garismatiese beweging te kan vertel, is dit nodig dat ' $n$ mens eers so ' $n$ bietjie moet praat oor die agtergrond waaruit hierdie hele beweging voortgekom het. Die garismatiese beweging is 'n beweging van ons eie tyd. Maar hy het ook soos al die dinge waarmee ons as mense te doen kry, sy wortels in die geskiedenis. Die garismatiese beweging is ' $n$ klein Amerikanertjie. Hy is in Amerika gebore en hy het twee voorouers gehad soos wat alle mense twee voorouers behoort te hê. Daardie twee voorouers van hom is die Pentecostal Movement en die New Pentecostal Movement wat in Amerika ontstaan het aan die begin van hierdie eeu en 'n paar jaar daarna. Hierdie Pentecostal Movement, as ons in Afrikaans daaroor wil praat, moet ons sê dit is die pinksterbeweging wat in Amerika ontstaan het. Ons weet almal dat die Heilige Gees op Pinksterdag uitgestort is. Daarom kan ons ook verwag dat hierdie bewegings op ' $n$ besondere wyse hulle sal besig hou met die Heilige Gees. Wat daar in Amerika gebeur het aan die begin van ons eeu is dat daar 'n dominee in ' $n$ kerk was wat toe besluit het dat die Amerikaanse kerke te dood is en hulle met ander woorde nie die instrument van die Heilige Gees kan wees nie want die Heilige Gees is lewendig en hy is kragtig. Toe het hy besluit: Dit ontbreek die kerke aan die Gees van God, hulle het nie die Gees van die Here nie. Daarvandaan het hulle toe verder gegaan en begin met die hele gedagte dat ' $n$ mens ' $n$ Geesdoop moet ontvang. Jy moet deur die Gees gedoop word apart van jou gewone doop, anders kan 'n mens nie die tekens toon van die lewe wat die Gees aan die kerk gegee het nie. Hierdie groep was 'n suiwer sektariese groep. Hulle het gebreek met die kerke en dan het hulle die kerke altyd daarvan beskuldig dat die kerke morsdood is en dat hulle self dan eintlik lewendig is en die ware Christene in die wêreld is. Soos dit maar altyd met alle sektes in die wêreld gaan, is hulle eintlik baie eensaam omdat hulle dink dat hulle die enigste van hulle soort in die wêreld is en dat daar nie nog ander Christene ook is nie.

'n Rukkie later het daar in die Episkopaalse Kerk in Amerika 'n nuwe pinksterbeweging ontstaan, die New Pentecostal Movement. Een van die, of liewer gesê die stigtersfiguur van daardie beweging 
was 'n sekere ds Bennet wat naderhand geskors is uit sy eie kerk. Hy het toe vir hom 'n groep bymekaar gemaak wat hy 'n teologiese skool genoem het waar hulle dan die Bybel kon bestudeer. Vir daardie groepie het ds Bennet voorgesê en dit is 'n storie wat hy nou vertel, wat toe eindelik die deurslag gegee het vir die stigting van die hele New Pentecostal Movement, dat hulle die Bybel moet ondersoek om te kyk of dit so is dat 'n mens ook nog behalwe vir jou gewone doop, deur die Heilige Gees apart gedoop moet word. En nou vertel hulledat die sowat 33 studente heeltemal onafhanklik van mekaar toe die Nuwe Testament ondersoek het en eenparig tot die besluit gekom het dat die Bybel dit duidelik leer dat 'n mens nog ' $n$ aparte doop met die Heilige Gees moet ondergaan om 'n Christen te kan wees en om die vrugte van die Gees te kan dra. Hierdie twee pinksterbewegings het toe eintlik saamgesmee in die kerklike lewe van Amerika en uit hulle is uiteindelik die garismatiese beweging gebore.

Daar was tog ' $n$ onderskeid tussen hierdie twee, die Pentecostal Movement en die New Pentecostals soos hulle hulself noem. Pastoor Justus du Plessis van die Apostoliese Geloofsending se broer, David is op die oomblik die leier van die New Pentecostal Movement in Amerika. Die Pentecostal Movement was suiwer sektaries. Hulle het gebreek met al die kerke en wil van die gedagte van 'n kerkvorming niks weet nie. Hierdie nuwe pinksterbeweging onder leiding, veral later van David du Plessis, het meer begrip geopenbaar vir 'n georganiseerde kerke en hulle het hulleself dan ook op ' $n$ baie meer definitiewe manier georganiseer en, soos die apostoliese sektes die laaste jare hier by ons aanhoudend sê dat hulle die vierde Afrikaanse kerk is, het hierdie beweging homself daar in Amerika al meer begin beskou as nog 'n Amerikaanse kerk, en dan eintlik baie graag gemaak asof hulle die werklike kerk is. Maar toe het daar uit hierdie twee bewegings ' $n$ invloed, die garismatiese beweging, voortgekom. Die garismatiese beweging was dan eintlik ' $n$ baie goeie kruising tussen daardie twee strominge in die sin dat hulle ook'n pinksterbeweging is wat beweer dat die kerke dood is deur die invloed van die teologie en die teoloë. Hulle sê die predikante is mense wat met hulle verstand die evangelie doodgemaak het. En aan die ander kant het hulle gesê dat die bestaande kerke wat nou so dood is deur die teologie, eintlik weer van binne af nuut gemaak moet word en húlle is die regte mense wat daardie beweging aan die gang gaan sit. Daarom wou hulle nie bedank uit hulle kerke soos wat die meeste sektariërs maak en dan 'n aparte groepie vorm nie. Hulle het in hulle kerke gebly en daar het hulle net hierdie gedagte van die pinksterbeweging ingedra waar hulle dan gesê het dat die kerk nuut gemaak moet word deur met die Gees gedoop te word en dan die vrugte van die Gees te dra. 
Hier in Suid-Afrika het hierdie garismatiese beweging ook aanklank gevind en hier is eintlik twee groepe mense wat die garismatiewe beweging as 'n nuwe verlossing as't ware aangegryp het. Dit is die Apostoliese Geloofsending, wat hulleself as die wettige familielid en voortsetting van die garismatiese beweging in Suid-Afrika beskou. Dan het ons hier in een van ons susterkerke so 'n klompie predikante en predikantsvroue wat goeie garismatikers geword het, soos hulle hulleself noem. In die stil en rustige Vrystaat het daar op 'n goeie dag ' $n$ domineesvrou begin om duiwels uit te drywe - tot die duiwel van naelbyt. Hulle sê dit was 'n vreeslike gestoei met die duiwel daar in die konsistorie om hom uit daardie jong man wat sy naels so opgeëet het, uitgedryf te kry. Die saak het verder gegaan en dit het naderhand daarop uitgeloop dat daar bietjie meer as ' $n$ jaar gelede onder andere sewe studente geskors is omdat hulle hulle weer laat doop het. Dit het al so ver gevorder dat, as die koerantberigte waar is, daar'n kwessie van dertig predikante is wat hulle self weer laat doop het en wat nou saam met daardie Uys-familie van Bethlehem in die Vrystaat eintlik besig is om hulle eie aparte eredienste op ' $n$ besondere manier te hou.

Met ander woorde die aangeleentheid is nou nie meer vreeslik ver van ons af nie. Maar dit is nie net Suid-Afrika waar hy aanklank gevind het nie. Ons kry hom vandag oor die hele wêreld. In elke Christelike kerk, is daar ' $n$ beweging wat homself die garismatiese beweging in die kerk noem.

Nadat iets oor sy herkoms gesê is en wat die geestesklimaat is waaruit hy gebore is en watter opgang hy in die wêreld gemaak het, sal dit goed wees om daardie kind van die Pentecostal en New Pentecostal Movements in Amerika nader te beskrywe.

Die garismatiese beweging, soos ek reeds gesê het, is 'n pinksterbeweging, maar hulle gebruik nie die naam pinkster soos die ou Pentecostals dit gedoen het nie. Hulle gebruik juis die naam garismatiese beweging. Maar dit verwys ook direk na die Heilige Gees. Want die garisma of die garismata is dan die genadegawes wat die Heilige Gees uitdeel. Dit kan gelees word in I Korintiërs 12, Romeine 12 en ook daarvan in Efesiërs 5. Die gawes wat die Heilige Gees uitdeel, is die garismata. En as hierdie mense hulleself die garismatiese beweging noem, sê hulle dat hulle eintlik die beweging is wat die gawes van die Heilige Gees besit. Daarom kan 'n mens verwag dat by hierdie mense in die eerste instansie daar iets oor die Heilige Gees geleer sal word. Dit is dan ook hulle hoofkenmerk want hulle sê dat hulle voortdurend besig is om met die Heilige Gees besig te bly. Oor die hele wêreld kan 'n mens hulle geskrifte lees, maar hulle praat nie uit een mond nie. Hulle sê baie verskillende dinge, selfs oor die Heilige Gees wat by hulle dan eintlik die middelpunt van hulle ge- 
dagtes en 'n mens wil daarom sê die sentraalste gedagte is in die dinge wat hulle dink en wat hulle leer. Maar as 'n mens hulle geskrifte lees, is daar' $n$ paar dinge wat ons wel kan sê wat min of meer by al hierdie verskillende garismatiese groepe voorkom en dit is dat hulle van die Heilige Gees en van hulleself ' $n$ bepaalde opvatting het. In die eerste instansie sê hulle die gawes van die Heilige Gees is só dat dit dade is wat 'n mens moet doen. Hulle lê 'n oordrewe klem op handelinge, op aktiwiteite, sodat ons hulle eintlik kan beskryf met die woord "aktualiste". Hulle is 'n vorm van die moderne aktiviste wat oordrewe klem lê op die bedryfwigheid - dit wat gedoen word. Terloops kan gesê word dat dit altyd 'n kenmerk is van al die mense wat glo aan werkheiligheid, die mense wat hulle self wil salig werk. Hulle word eintlik tot waansin gedryf omdat hulle nie genoeg kan doen nie.

Daar is ook nog 'n ander belangrike kenmerk en dit is dat hulle sê dat elke mens die Heilige Gees afsonderlik moet ontvang sodat hulle op die enkeling 'n oormatige klem lê. Elkeen van hierdie mense is in die grond van die saak eintlik 'n baie eensame wese, want hy is in die hele wêreld eintlik die enigste van sy soort. Een van die ou teoloë het van homself vertel: dat hy met sy eerste bekering so heilig was dat selfs die engele in sy teenwoordigheid skaam gekry het. Dan sê hy, dat hy die Vader dank dat hy hom kon bekeer van daardie bekering sodat hy 'n Christen en 'n gelowige kon word. Dit sal die garismatikers goed doen om van hierdie getuienis van Kohlbrugge, kennis te neem.

In elk geval, hierdie mense is in die grond van die saak wesenlik eensame mense want hulle is elkeen, soos reeds gesê is, enig van sy soort in die hele wêreld, omdat hy op sy eie besondere manier die doop met die Gees ontvang het en daardie gawes wat die Heilige Gees uitdeel as ' $n$ mens Hom ontvang, op sy eie besondere manier ontvang het.

Die derde saak wat hulle in die verband eintlik baie duidelik stel, is dat deur dié toerusting van die Heilige Gees hulle vervul word en dan gebruik hulle 'n woord van Paulus, met "gees en krag". Daardie mense is in hulle eie opvatting en volgens hulle eie gedagtes werklik geestelike kragwesens. Want hulle verbeel hulle dat hulle alles kan doen wat hulle wil, soos hulle wil, omdat hulle nou die bepaalde krag ontvang het.

Vanuit hierdie agtergrond is dit dan vir ons duidelik dat hulle ' $n$ heel besondere opvatting van die Heilige Gees het. Ons sê in die kerk op grond van die Bybel, soos dit ook uitgedruk is in die geloofsbelydenis van ons Kerk, die Twaalf Artikels, die Geloofsbelydenis van Nicea en die Geloofsbelydenis van Athanasius, dat die Heilige Gees die derde persoon van die goddelike Drie-eenheid is wat saam 
met die Vader en die Seun een Heilige God is, ongeskeie en onvermeng. Met ander woorde, ons sê die Heilige Gees is 'n goddelike persoon. Vir hulle is Hy eintlik baie meer' $\mathrm{n}$ krag. As hulle gedoop is met die Heilige Gees, is dit eintlik 'n krag wat in hulle ingegiet is, waardeur hulle as't ware in staat gestel word om allerhande dinge te doen. Nou sê hulle ook so: As hulle hierdie doop met die Heilige Gees ontvang het, het hulle 'n nuwe krag. Hierdie doop met die Heilige Gees waardeur hulle hierdie nuwe krag ontvang, is nie 'n ding wat die Here gee nie, maar wat 'n mens moet soek en wat jy deur jou menslike inspanning uiteindelik ook self kan verkry. So is hulle voortdurend nog op soek. As hulle nog nie volgens hulle eie ervaring die doop met die Heilige Gees ontvang het nie, soek hulle na daardie doop totdat hulle hom gekry het. Hulle skryf ook voor hoe 'n mens dan die Heilige Gees moet kry. Hulle verwys daarvoor na die Bybel wat hulle dan heeltemal op hulle eie manier uitlê. Hulle sê daar staan dat hierdie geslag nie anders verbygaan as deur vas en gebed nie. Dit wil sê deur'n soort van gewelddadigheid gooi hulle hulleself eintlik in die gebed, vas en dergelike dinge, om so die Heilige Gees eintlik te dwing om te kom. Op die manier kry hulle dan daardie geestesdoop en ontvang hulle daardie krag. Dan sê hulle as 'n mens die Heilige Gees ontvang het, vertoon hy bepaalde kenmerke, wat die Heilige Gees aan 'n mens gee. Dit is dan die sogenaamde garismata - die genadegawes. Hulle sê die uitstaande kenmerk daarvan is dat as 'n mens die Gees ontvang het, weet jy aan daardie kenmerke in jou lewe, dat jy met die Gees gedoop is. Daardie uitstaande kenmerke is dan vir hulle dat ' $n$ mens in tale begin praat, dat hy wonderlike genesings kan doen soos Dan Bosman beweer, en dat hy duiwels kan uitdryf. Dit is die hoofkenmerke van die gawes van die Heilige Gees.

Maar nou is dit interessant: Hulle noem eintlik maar net hierdie drie, terwyl Paulus nie minder nie as drie en twintig genadegawes noem wat die Heilige Gees gee. Daaruit kan ons aflei dat hulle tog nie besig is met die gawes wat die Gees op die Bybelse manier gee nie. Hulle het net sekere dinge uitgesonder wat dan vir hulle by uitstek die gawes van die Heilige Gees is en wat dan bewys lewer dat'n mens die Gees ontvang het as jy daardie dinge kan doen. Dan, soos hulle sê, betoon hulle geesteskrag, dit is om in tale te praat, om hierdie wonderlike genesings te kan doen en om die duiwels te kan besweer en uitdryf. Wat baie interessant in die verband is, is dat hulle sê: Die Here Jesus het hierdie dinge gedoen en nou moet ons dit ook doen. As 'n mens dan vir hulle sê: Maar die Here Jesus het nie net mense gesond gemaak nie maar Hy het mense ook lewendig gemaak en dan vra waar die dooies is wat hulle lewend maak sê hulle nee, nee, nee maar dit is nie nodig nie. Jy kry nie 'n verdere antwoord uit hulle nie. As jy vir hulle verder sê dat die Here Jesus byvoorbeeld 
ook die storm op see stilgemaak het, dus natuurwonders gedoen het en vra waar die natuurwonders is sê hulle nee, nee, nee, die weerburo verskaf vir ons die weervoorspellings. Daaruit weet ons hoe om op te tree. So ons het nie nodig om storms stil te maak nie. Dit is die lekker manier waarop hulle uit hierdie vrae uitkom. Ook wat die duiweluitdrywery betref, is dit presies dieselfde. Oor die praat in tale vertel hulle die wonderlikste stories. Dr F P Möller die president van die Apostoliese Geloofsending, beweer byvoorbeeld dat ' $n$ man wat nie 'n woord Sotho ken nie, wat in sy lewe nooit 'n Sotho gesien het nie of nog nooit Sotho gehoor het nie, in tale begin praat het in een van hulle dienste. Toe het daar iemand anders in die kerk gesit wat sê dat daardie man perfekte Sotho praat. Dit word nou vir ons duidelik dat hulle 'n heel besondere opvatting het van die Heilige Gees, dat Hy so ' $\mathrm{n}$ krag is dat as hulle Hom gesoek het en in die doop met die Gees ontvang het, $\mathrm{Hy}$ vir hulle die vermoë gee om veral in tale te kan praat, wonderlike genesings te kan doen en duiwels te kan uitdryf.

Hiermee saam is dit vir ons baie duidelik dat as ons oor die Heilige Gees praat, ons uiteindelik ook oor die kerk moet praat. Ons bely in ons geloofsbelydenis: "Ek glo in die Heilige Gees, ek glo ook een heilige, algemene Christelike kerk, die vergewing van sondes, die wederopstanding van die vlees en die ewige lewe." Dit kan ons sê, is alles die werk van die Gees: Die Christelike kerk, die vergewing van sonde, die wederopstanding van die vlees en die ewige lewe. Dat ons dit alles kan glo, is die werk van die Gees. Die Apostoliese Geloofsending kom uiteindelik ook by die kerk uit. Maar sê hulle: Ons bely heeltemal verkeerd as ons sê dat op grond van die Bybel die kenmerke van die ware kerk die regte prediking van die Woord, die suiwere bediening van die sakramente en die regte uitoefening van die tug is, soos ons dit bely in die Nederlandse Geloofsbelydenis, artikel 27. Hulle sê dis nie waar nie, dis nie die kenmerke van die kerk nie. Die kenmerke van die ware kerk is dat hy met die Gees gedoop moet wees; dat hy in tale moet praat; dat hy wonderbaarlike genesings moet doen en dat hy duiwels moet uitdryf. Hulle sê dat die kerk hierdie groot misverstand het om totaal ander kenmerke vir die kerk te gee, en daarom is dit hulle groot taak om die kerk van binne af weer reg te maak. Daarom wou hulle hulle ook nie afskei van hulle eie kerke nie. Hulle wou binne-in die kerke bly en wou dan, soos hulle sê met 'n nadere reformasie eintlik die kerk van binne af weer skoonmaak.

In die verband is dit interessant dat hulle ook Bybelse woorde op ' $n$ bepaalde manier gebruik. Hulle praat byvoorbeeld oor die gelykenis van die suurdeeg en die deeg, waar die Here sê dat daar ' $n$ klein bietjie suurdeeg in 'n groot klomp meel ingeknie word. Daarvan sê 
hulle: Die garismatiese beweging is nou eintlik die suurdeeg en hierdie onnosele klomp Christenmense wat hulle geloof bely het en wat almal gedoop is, dit wil sê die kerk, is eintlik die meel wat gered moet word en hulle moet nou eintlik hier van binne af as die suurdeeg die hele deeg suur maak, sodat hierdie hele kerk daardie kenmerke sal vertoon van die vreemde tale, van die genesings en van die duiwel uitdrywing.

'n Ander begrip wat hulle ook gebruik om hulleself mee te beskrywe, is dat die Bybel sê ' $n$ mens, siel en liggaam is. Die siel is dan eintlik die krag wat die liggaam aan die gang en aan die lewe hou. Daarvan sê hulle dat hulle die siel van die kerk is en hierdie ander groot massas van mense wat in die kerk se registers ingeskrywe word, daardie ou dooie lyf is wat niks kan doen nie, as hulle, as die siel van daardie lyf hom nie aan die lewe hou nie. Dit is duidelik dat hulle in hierdie verband op 'n baie meerderwaardige en hoogmoedige wyse oor hulleself praat en ook oor hulle betekenis in die kerk en vir die kerk, volgens hulle eie opvatting.

Om hierdie dinge oor die Heilige Gees en oor die kerk wat eintlik die werkplek van die Heilige Gees is, te kan sê, maak hulle op 'n besondere manier van die Bybel gebruik. Daarom moet ons ook iets sê oor hulle opvatting van die Bybel. In die teologiese taal moet ons hulle fundamentaliste noem. In die praktyk werk dit so uit dat hulle alles wat in die Bybel geskryf staan, eintlik as 'n model sien wat deur die mense van vandag nageboots moet word. As die Here Jesus Lasarus opgewek het - daar steek hulle vas. Dit is nou nie 'n goeie voorbeeld nie. As die Here Jesus die blinde genees het, sê hulle: Nou moet jy ook' $n$ blinde kan genees. As die Here Jesus daardie skare gevoed het met die bietjie brood, sê hulle: Jy moet dit ook doen. Hulle sê as die apostels daar op Pinksterdag in vreemde tale kon praat, moet jy ook in vreemde tale kan praat. En as ons lees dat die Here Jesus die duiwel uitgedrywe het uit die maansieke kind, sê hulle: Jy moet ook die duiwel kan uitdryf. Met ander woorde, vir hulle is die Bybel modelle wat nageboots moet word. Die Bybel sê nie vir hulle wat die Here God vir ons gedoen het deur die Here Jesus Christus en deur sy Gees wat Hy aan ons gegee het nie. Hy sê nie vir ons wat ons moet glo nie. Volgens hulle stel hy vir ons die patroon waarvolgens ons moet optree om daardie dinge self te kan doen. Met ander woorde: Ons kan eintlik sê dat hulle besondere soort van Bybelgebruik van so ' $n$ aard is dat jy nie eers uit die Bybel met hulle kan redeneer nie. Dit het ook duidelik geblyk. As daar by die uitstorting van die Heilige Gees gepraat word oor die spreek in vreemde tale, en Paulus praat later in I Korintiërs 12 onder totaal ander omstandighede van hierdie spreke in tale, sê hulle die twee dinge moet jy direk aan mekaar knoop want hulle hou verband met mekaar. Die gevolg is 
dat jy met hulle nie 'n verstandige woord oor die Bybel kan praat nie want hulle gebruik die Bybel soos dit hulle pas, as modelle wat in die lewe van vandag nageboots moet word, anders is jy nie Christen nie, het jy nie die Gees nie en betoon jy nie Gees en krag nie.

So, as ons moet sê wat hulle leer of belydenis is, moet ons in hoofsaak drie dinge wat vir ons baie opvallend en uiters bedenklik is, noem naamlik hulle opvatting van die Heilige Gees, hulle beskouing oor die kerk en dan hulle Skrifgebruik wat op ' $n$ bepaalde opvatting van die Bybel as sodanig berus. Dit is die dinge wat hulle leer en bely. Hulle leer en hulle belydenis is die eerste kenmerk waaraan hulle geken kan word.

Die tweede kenmerk word ook kortliks bespreek en dit is hulle $l i$ turgie - dit is die erediens wat ons hou. Hulle opvatting van die erediens, is baie eienaardig en in ' $n$ sekere sin eintlik interessant en selfs vermaaklik. Ons sê die erediens word saamgeroep deur die gepreekte Woord en die uitgedeelde sakramente. Met ander woorde: Ons kom op Sondag bymekaar omdat die Here vir ons sê: Kom julle hier. Ek wil met julle praat. En deur alles wat ons daar in die kerk doen: as ons belydenis doen, as ons in ons hart saam bid as die predikant voorbid en as ons daar sing, antwoord ons op daardie dinge wat die Here vir ons sê. Ons sê dus dat die erediens'n gesprek is tussen die Here en sy gemeente wat die Here deur die Woord wat gepreek word en deur die sakramente wat uitgedeel word self bymekaar roep. Hulle het heeltemal 'n ander opvatting daaroor. Hulle sê dat die mense daar bymekaar kom om hulle self godsdienstig te kan uitlewe. Dit beskou hulle dan eintlik as religieuse selfverwesenliking. 'n Mens kom eers godsdienstig tot homself en tot sy reg as hy daar kom om saam met garismatiese geesgenote sy godsdienstige ervarings uit te lewe. Dit lei daartoe dat hulle allerhande eienaardige dienste het waar daar byvoorbeeld geleentheid gegee word om in tale te praat, want hulle sê dat as 'n mens in tale praat, oorval dit jou nie soos 'n swaar weer nie. Jy kan dit selfs terughou as jy wil: As jy wil, kan jy praat en as jy nie wil nie kan jy stilbly. Daar is geleentheid veral vir duiweluitdrywings, vir die sogenaamde gebedsgenesing en ook geleentheid vir die ontvang van die Heilige Gees, of die doop met die Heilige Gees. Die erediens is die geleentheid waar hulle dan eintlik hulleself as't ware weer versterk met die kenmerke van die "ware kerk" wat hulle moet vertoon, naamlik om in vreemde tale te praat, genesings te doen en om duiwels uit te drywe. Hulle sê erediens is iets wat baie krag van 'n mens verg. Dr Kempff van die Gereformeerde Kerk het rondgery en bandopnamens gemaak van hulle dienste. As 'n mens daardie dinge hoor wat daar plaasvind! Daar is 'n vrou wat in tale praat van wie hy 'n opname gemaak het, wat meer 'n brabbeltaal as iets anders gebesig het. Hulle sê dis 'n vreemde taal waarin sy praat. 
Dit is min of meer hoe hulle eredienste verloop. Dit bevat niks van die goeie orde, van die rustigheid en die vrede en van die verstandige woord wat die Here self vir ons uit sy Woord uit sê en van die gebruik van die sakramente nie. Dit is 'n emosioneel oorbelaste, oorspanne, emosionele belewenis. Die twee hoofkenmerke waaraan hierdie mense geken kan word, is daardie snaakse leer van hulle en hierdie eienaardige eredienste.

Om saam te vat: Die kenmerke van hierdie garismatiese beweging of laat ons liewer sê die beskrywing van hierdie garismatiese beweging wat ons moet gee, is die volgende: Dit is sektaries en in hierdie opsig ' $n$ nuwe sektariese beweging. By die ou sektes bestaan die tweede deel van hulle sektewees daaruit dat hulle van die kerk afgeskei het. Die garismatikers wil nie afskei nie. Hulle wil binne in die kerk 'n dwaalleer handhaaf, want die ander deel van 'n sekte is dat hulle ' $n$ dwaalleer aanhang. Die tweede wat ons oor hulle moet sê, is dat hulle beswaarlik oortuig wil word van ander opvattings van die Heilige Gees, die kerk en die Bybel as dié wat hulle handhaaf, nie omdat hulle nie daardie opvattings uit die Bybel self kry nie maar dit van buite af in die Bybel indra. ' $n$ Mens wat so met die Bybel omgaan en wat eers sy opvattings vorm en hulle dan in die Bybel indra, kan uit die Bybel uit enige ding bewys. Ons sê ook: Elke ketter het sy letter. Jy kan hom nie met die Bybel weerlê nie omdat hy die Bybel op'n ander manier gebruik as wat ons hom gebruik. Die derde opmerking wat ons moet maak is dat hier ' $n$ baie gevaarlike beginsel op die spel kom: die veranderde opvatting van wat ' $n$ erediens eintlik is. Die samevatting van dit alles is dit: $\mathrm{Al}$ is dit die herlewing van ' $\mathrm{n}$ ou sekte en 'n ou sektariese gedagte, wat eintlik so oud soos die Christelike kerk self is, bly hierdie beweging ' $n$ vraag aan die kerk en aan onsself: God het sy Gees aan die kerk gegee en die vraag is of ons dit ernstig neem en dit ook ernstig uitleef. 